\title{
STAKEHOLDER ENGAGEMENT IN GREEN PLACE BRANDING: A FOCUS ON USER-GENERATED CONTENT.
}

Diletta Acuti, University of Florence

Valentina Mazzoli, University of Florence

Laura Grazzini, University of Florence

Gaetano Aiello, University of Florence

\begin{abstract}
The purpose of this research is to investigate how the green image of a city can affect potential visitors' attitude toward the city in the context of user-generated content. The study adopts a $2 \times 2$ experimental design in which the greenness of the city image and the social distance between the users and the authors of social media content are examined. The results demonstrate that green image has a significant effect on attitudes toward cities. Moreover, the effects of social media content vary according to the perceived social distance between the author of the post and potential visitors. This study contributes to the literature by assessing the role that social media content plays in place branding and communication. Furthermore, it provides relevant insights on how institutions should enhance the sustainable resources of cities with their environmental policy and encourage the generation of content from various stakeholders to contribute to the development of a city's image.
\end{abstract}

Keywords: Stakeholder engagement; Environmental policy; Green city; Place branding; City image; City identity; User-Generated Content

Article classification: Research paper 


\section{Introduction}

Nowadays, social media has become an important part of everyday life, serving as an alternative form of communication that supports existing relationships in a manner that can enrich the user's experience. Indeed, following the development of Internet information technology, the growth of social media has transformed the communication styles of billions of people and organizations. Of course, the digital environment also provides companies with platforms that can improve their brands and affect consumers' decisions (Dessart, Veloutsou, \& MorganThomas, 2015). Users can become active subjects who take part in the brand's image formation process through the content they generate on social media. Therefore, social media becomes a locus where brands and consumers interact, thus shaping purchase.

The tourism industry is especially affected by this phenomenon. In fact, digital environments have made users more informed, as they look for new ways to research travels. Instagram users, in particular, have had a profound effect on place brand image, electronic word of mouth (eWOM) via images, and comments about products, services, and places (Bronner \& de Hooge, 2011). Thus, Instagram is an important tool in the city branding process.

Different types of users contribute to the creation of the city image. Influencers often represent a reference point for their followers' choices. Regional "iger communities" that are committed to participatory/bottom-up territorial promotion strategies have emerged in recent years. Institutions seem to understand their relevance and have made them an integral part of their place branding activity (Thornton, 2014). Visitors also post pictures on Instagram that capture the reality of the places they visit. Content posted by different stakeholders is becoming increasingly sought after, as users often seek the advice of others while making decisions (Duhacheck et al., 2007). Specifically, users - and people in general - tend to like similar others more than dissimilar ones (Berscheid 1985). Although the growing role of social media in influencing consumer behaviour has been recognized by academics (Barger et al., 2016; Bedard 
\& Tolmie, 2018), very little research has focused on Instagram and its role in place branding (Bakhshi, Shamma \& Gilbert, 2014; Oliveira, 2015; Acuti et al., 2018). This study seeks to understand the role of user-generated content (UGC) in determining attitudes toward certain cities. In particular, the research investigates how the green image of a city - enhanced by contents posted on Instagram - influences the attitude of potential visitors. Moreover, the study investigates the moderating role of perceived social distance.

By applying an experimental approach, this research aims at contributing to the literature on city branding and user-generated contents in order to provide to managers and policy makers plausible explanations of certain individuals' behaviour and reactions related to the development of sustainable cities.

\section{Place branding}

As well as marketing includes the enhancement of a product or brand's position in the marketplace, place marketing concerns the improvement of a country's position in the global marketplace (Kotler \& Gertner, 2002). The process involves various stakeholder, such as government, citizens, businesses and it requires setting and delivering the incentives and managing the factors (i.e. image, attractions, infrastructure, and people) that might affect place buyers' decisions (Kotler \& Gertner, 2002). All these factors deal with different tasks of place branding. The rationale supporting place branding is that places such as countries, regions, cities, can be considered as brands. The American Marketing Associations defines brands as names, terms, signs, symbols, or designs or a combination of them intended to identify the goods and services of one seller or group of sellers and to differentiate them from those of competition. Accordingly, brands perform several functions, such as the differentiation of products, or the transmission of associations, values and emotions to consumers. Similarly, place branding aims at building a symbolic, comprehensive image of a place, including its exclusive features and 
people, and subsequently communicate this image both locally and internationally. Place branding has drawn attention from scholars in several disciplines, including marketing (Kavaratzis, 2005), communication (Sevin, 2014), public diplomacy (Gilboa, 2008), and public relations (Szondi, 2010). Although these different approaches help us to understand the complexity of this phenomenon, most research on place branding focuses on naming issues (e.g. Dinnie, 2015; Kavaratzis \& Ashworth, 2005). Nowadays, branding strategies have started to become exhausted as an increasing number of places have implemented branding practices to jostle for greater recognition in a more globalized environment (Bell, 2016). Several associated concepts are triggered in the individuals' minds when a place is named. Institutions, local governments, and local promoting organizations must manipulate these associations in order to improve their brand (Sevin, 2014). Thus, place branding focuses on the development of a positive brand identity (Freire, 2005) that can be defined as "the sum of place characteristic features and activities which differentiate it from other entities" (Klage, 1991, p.27). Like other forms of brand identity, place identity is often the result of a process that integrates the experiences of different stakeholders (Cai, 2002).

Following the rationale coming from product marketing literature, as place identity involves supply-side aspects of place branding, place image involves demand-side features (Pike, 2009). Place image can be defined as the beliefs, ideas, and impressions that users have toward a specific place (Kotler \& Gertner, 2002). It represents the "objective knowledge, impressions, prejudice, imaginations, and emotional thoughts an individual or a group might have of a particular place" (Jenkins, 1999, p. 1), so it is a mental picture of the tangible and intangible characteristics of a place. According to Kladou et al. (2016), place identity and place image influence each other, if only because place identity tries to leave impressions on others while place image mirrors external impressions and expectations. Integrating place identity and place image perspectives allows us to define place brands as a dense network of associations in the 
minds of consumers that are based on the visual, verbal, and behavioural expression of a place, as embodied through the aims, communications, values, behaviours, and general culture of stakeholders and overall place design (Braun, Kavaratzis, \& Zenker, 2013). Place brands are not owned or controlled by a single organization but are jointly developed and delivered by a network of public and private sector organizations. Indeed, various stakeholders contribute to the creation of place branding (e.g. Braun, Kavaratzis \& Zenker, 2013; Kim \& Ko, 2012; Kavaratzis, 2005). Most of studies focuses on tourists' viewpoint, given that tourists' perceptions might affect city attractiveness through word of mouth, their intention to revisit and their willingness to recommend to others (Kim \& Ko, 2012). Kavaratzis (2005) refers to institutions as mediators between the material substrate of social space and the social practices developed in that specific space. Institutions are place-making elements that help people form psychological associations with the place. Other studies, meanwhile, tend to focus on business organizations (local and foreign) that create the types of psychological associations involved in the development of place branding (Hankinson, 2010). Their role is relevant both in terms of contributing to the development of the city branding process and as addressees of this process. The brand images of the companies located in the region are important for the place image. With respect to residents, their interactions with each other and with outsiders obviously form the social milieu of a given place. Their role in the city branding process could be the result of a deliberate brand strategy, but it is more often a natural process. Given the role of several different stakeholders in the creation of place branding, it would be rash to suggest that this process is the result of a deliberative brand strategy, but rather is the result of a more organic process (Braun, Kavaratzis, \& Zenker, 2013).

As several stakeholders participating to the place branding process make it very complex, Web 2.0 and social media contribute to the further complexity of this process. Users are increasingly connecting in social media where they share personal stories and information that influence 
other users' behaviour, including where they go and what they purchase (Adams, 2012). Since social media provide spaces for people to communicate, they have also become an important source for users to find information about places (Buhalis \& Foerste, 2015). As a consequence, in recent years, a growing number of studies focused on the role of users and user-generated content in the place branding process (e.g. Andéhn et al., 2014; de Rosa, Bocci, and Dryjanska, 2017; Lund, Cohen, \& Scarles, 2017).

\section{User-generated content and city image}

Social media platforms are an important feature of everyday life, oftentimes encouraging consumers to share their personal stories, including what they buy and where they go (Lund et al., 2017). Social media consists of several different types of online platforms — for instance, blogs, review sites, media sharing, question-and-answer sites, social book-marking, social networking, social news, and wikis - providing users with spaces to communicate and share content on various topics, such as brands, places, or products (Buhalis and Foerste, 2015; Hao, Farooq \& Sun, 2018). Thanks to social media, people are elevating their role from "passive" consumers to active subjects that contribute to the creation of brands and communication strategies (Stewart \& Pavlou, 2002; Liu, Burns \& Hou, 2017). Thus, according with Kim and Johnson (2016) consumers are able to influence other consumers' decision-making and consumption activities on a level not previously seen.

Social media content is just one part of a rich source of online information known as UserGenerated Content (UGC; Koltringer \& Disckinger, 2015). UGC includes "published content on a publicly accessible website on a social networking site that needs to show a certain amount of creative effort, and it has been created outside of professional routines and practice" (Kaplan \& Haenlein, 2010, p. 61). This content encourages a form of empowerment by providing an outlet for self-expression, extending individual reach, and allowing personal opinions to 
influence markets (Labrecque et al., 2013). Although UGC is related to the electronic-word-ofmouth (e-WOM) concept, it is not identical. Indeed, e-WOM is defined as any positive or negative statement made by potential, actual, or former customers about a product or a brand that is made available to a multitude of users (Hennig-Thurau et al., 2004). UGC, by contrast, relies on the influence it has on other individuals (Jalilvand et al., 2012) because it reduces the perceived distance between the source of information and the receiver, thereby creating trust between the user and the source of the content (Fotis et al., 2012). UGC also influences brand perceptions, thus enriching the network associations that characterize both brand image and, more broadly, brand knowledge (Zhang \& Sarvary, 2014).

Like product brands, place brands are shaped by UGC, introducing a host of complex issues in destination marketing (Andéhn et al., 2014). According to Foroudi et al. (2016), social media and UGC work as moderators in shaping the favourability of place branding. Tourism is particularly affected by UGC because travel experiences represent the third most popular topic on Facebook after music and television (Bertino, 2014). Places inspire individuals to take countless photos of their experiences, while social media offers a suitable outlet for sharing these experiences (Lund et al., 2017). This content has the potential to influence prospective tourists who go online looking for information about various destinations (Martin et al., 2007). Because of this, place branding should be seen not only as a negotiation process between places and target audiences (Sevin, 2014), but also the product of various interactions between local institutions and the people who come together to create content (Andéhn et al., 2014). Because of the experiential nature of touristic products, UGC serves as a relevant information source for potential tourists. Indeed, there is a higher perceived credibility of opinions expressed in UGC than in institutional tourism information sources because of the perceived independence of the message source (Alcázar et al., 2014). Therefore, UGC introduces a greater complexity in destination marketing, boosting the need to examine both textual and visual information 
provided to understand the complete structure of destination image formation in the online market space (Choi et al., 2007).

\section{Green city branding}

Urbanization has enormous environmental consequences, both locally and globally. City dwellers are currently responsible for up to $70 \%$ of the world's greenhouse gas emissions (The Green City Index, 2012). Extensive urban development swallows up arable land and vital green spaces, while urban residents put pressure on energy and water resources and waste management. Nowadays, more than half of the world's population lives in cities, and some forecasters expect that 70\% of people will live in urban areas by 2050 (United Nations, 2014). For these reasons, the importance of cities as a means through which to address the challenge of sustainable development, concepts of sustainable cities and urban sustainability have gained significant ground internationally (Bulkeley \& Betsill, 2005). The United Nations recently reaffirmed the importance of sustainable cities in its Sustainable Development Goals (UN SDG), defining the direction to be taken in the formulation of global policies up to 2030. In this context, cities that are sustainable can be viewed as driving forces for the reduction of global environmental change and as facilitators of a more sustainable development worldwide. Moreover, sustainable cities assume a great importance for the quality of life of residents in the actual increasingly urbanized society. In this sense, greener cities represent a point of reference for well-being and sustainability becomes a strength in the city branding strategy development (Van Kamp et al., 2003; Yan et al., 2018). For this reason, many cities are actively engaged with "urban greening", addressing urban impacts and making cities more attractive, biodiverse, and healthier (Ahern, 2013).

Cities, of course, provide many green spaces to both tourists and the local population, including public parks and other types of public spaces (Rahmawati et al., 2018). According to Acuto (2012), municipal leaders around the world have begun enhancing their green resources in order 
to create a city brand that matches the expectations and perceptions of residents, travellers, and other stakeholders. One of the driving forces behind green place branding is the willingness to transform places into clean and attractive urban settlements. Indeed, place branding strategies have been increasingly deployed in urban environmental policy-making (Ayuso, 2006; Andresson, 2016). Many research has demonstrated a positive link between green space in urban areas and well-being (Tzoulas et al., 2007). Many municipal leaders have used "greenness" as a branding tool that presents their cities as attractive liveable places for residents, companies, and visitors alike (Insch, 2011). As Anderberg and Clark (2013) have argued, since sustainability is a key factor in creating a successful urban milieu, it will occupy a similarly important position in city branding strategies. According to Chan and Marafa (2016), a "green city image" is a construct that indicates the use of green resources — such as parks, green spaces, trees, and pastoral landscapes — to market a city and improve/ revitalize its image (Jim, 2002; Jim and Chen, 2006). The recent trend towards sustainable living (Korhonen, Niemeläinen \& Pulliainen, 2002; Harjoto \& Salas, 2017) and a greater appreciation of green brands (Kang \& Hur 2012; Gershoff \& Frels, 2014) has forced institutions and organizations to think about green aspects of their city branding activity, with special emphasis on their ability to shape the behavior of different stakeholders and influence their choices. Indeed, the literature suggests that a green image can positively affect different kinds of stakeholders, including potential visitors (Gulsrud, Gooding, \& Van Den Bosch, 2013). As a result, the authors have drawn up the following hypothesis:

H1: The more a city is perceived as having a green image, the more positive are people's attitudes towards the city. 


\section{Social Distance as a Moderating Variable}

Construal level theory (CLT) explains how psychological distance influences mental representation, judgment, and choice (Liberman \& Trope, 1998; Trope \& Liberman, 2003; Trope \& Liberman, 2010). According to CLT, objects, events, and individuals can be perceived as being psychologically near or distant, suggesting that the more psychologically distant an object is from the receiver of the message, the more abstract the construal is (Line et al., 2016). Psychological distance can vary in terms of time, space, social distance, probability, or any other dimension that prevents consumers from focusing on themselves in the here and now.

Social distance is the perception that a phenomenon is endorsed by a person that is either similar or dissimilar to the observer (Trope \& Liberman, 2010). The distinctions between the self and others, similar and dissimilar others, and in-group (i.e. similar others) and outgroup (i.e. dissimilar others) members factor into the understanding of social distance. Liviatan, Trope, and Liberman (2008) define social distance using interpersonal similarity, with similar others being perceived as socially closer to oneself than dissimilar ones. If one person is less similar to another, then they will typically seem more socially distant. Therefore, behaviour performed by a dissimilar other would be represented at a higher level of construal than behavior performed by a similar other (Fiedler et al., 1995).

Previous research has found that people tend to like similar others more than dissimilar others (Berscheid, 1985; Byrne, Clore, \& Worchel, 1966), and are typically more emotionally invested in close others than distant others (Andersen et al., 1998). One might, therefore, expect that people would be more involved in processing information about a similar individual than a dissimilar one, and lend more credence to their judgments. In this regard, social media literature indicates that peers (e.g., similar people) are the primary socialization agents, beyond family members (Wang, Yu \& Wei, 2012; Köhler et al. 2011). As such consumers tend to interact with peers about consumption matters, which greatly influence their attitudes toward products, 
brands and services (Wang et al., 2012; Schivinski \& Dabrowski, 2016). Identification and perceived closeness with the group is therefore a key determinant of virtual community participation (Dholakia, Bagozzi, \& Pearo 2004), such that when it has been established, the person develops we-intentions (Bagozzi \& Dholakia 2002), places greater value on relationships with the community (Nambisan \& Baron 2007), and is willing to engage in community activities (Algesheimer, Dholakia, \& Herrmann 2005). Moreover, when people feel to be closer to some social group they tend to conform with group norms and modify their attitudes and behaviours based on peers' expectations (Cialdini \& Goldstein, 2004).

Tourism literature has shown that UGC is perceived as similar to recommendations provided by friends, family members or even "like-minded souls" (Zeng \& Gerritsen, 2014). Moreover, social media contents shared by tourists are seen as more trustworthy than information provided by the destination or tourism service provider (Fotis et al., 2012; Yoo et al., 2009). Based on this, we expect that social media contents published by users perceived as socially closer to the self, more likely influence the attitude and the behaviours of other users. Specifically, we argue that people have more positive attitudes and a greater perception of the city greenness when social media contents are shared by similar individuals (i.e., visitors) compared to dissimilar ones (i.e., municipality). Formally:

H2: The less social distance there is between users of social media, the more positive the visitor's attitude toward the city will be.

H3: The social distance between users of social media moderates the relationship between the perceptions of city greenness and attitudes towards the city. The positive relationship between perceptions of city greenness and attitudes towards the city is amplified (reduced) when the social distance between the generator and receiver of information is low (high). 


\section{Conceptual Framework}

Figure 1 displays the conceptual framework of our study. H1 tested our core prediction, in that the greenness of the city exerts more positive potential visitors' attitudes toward the city, thus proving the main effect of the green image of the city on visitors' attitudes. We also examined how the social distance between users of social media moderates the effect of the greenness of the city on visitors' attitudes. In doing so, we tested both the main effect of social distance (H2) and the interaction effect between the green image of the city and the social distance on potential visitors' attitudes (H3) (Heyes, 2017).

Figure 1 - The Model

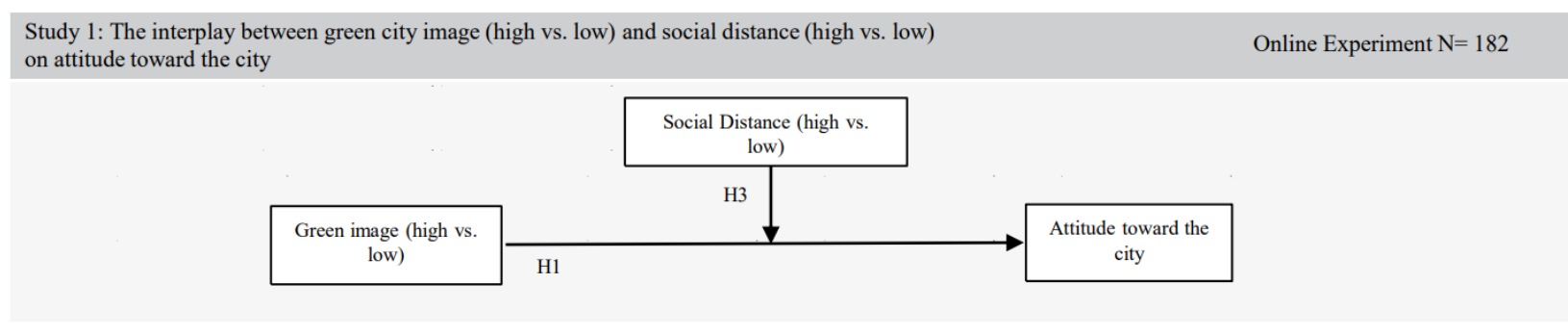

\section{Methodology}

\section{The sample}

In order to test the hypotheses, authors developed a $2 \times 2$ experimental design in which high/low green image and high/low social distance are examined. Authors involved in their experiment a specific segment of potential visitors that is the green lifestyle segment. Green lifestyle has been conceptualized in several ways (Florenthal \& Arling, 2011), including everyday green activities (Divine \& Lepisto 2005) and product-specific attitudes and behavioral intentions (Laroche et al. 2001). This study, however, focuses on environmental activities, values, and perceptions (Do Paço \& Raposo 2010). As a result, authors sent questionnaires to members of social media groups devoted to sustainable living. This choice enabled us to have a more homogeneous group of respondents, according to Geuens and De Pelsmacker (2017). Data were 
collected in Italy and the questionnaires were written in English, translated to Italian and then back-translated into English. The final questionnaire has been revised by two English mother tongue marketing experts. The back-translation method was conducted in order to ensure that the Italian version of the questionnaire had the same content as the English version (Sekaran, 1983). The groups the authors focused on were not open to the general public (membership requests needed to be approved in advance) and had more than 20,000 members. Measuring the green lifestyle of users was accomplished through the 7-point Likert scale provided by Florenthal and Arling (2011) composed by 7 items (I guess I've never actually bought a product because it had lower polluting effect; I make a special effort to buy products in recyclable containers; I have switched products for ecological reasons; I have attended a meeting of an organization specifically concerned with bettering the environment; I subscribe to ecological publications; I recycle at home or work; I keep track of my congressman and senator's voting records on environment issues). The average number of responses was 4.70 , with a variance of 1.30. A total of 182 respondents participated in the study - $68 \%$ were women. $58.2 \%$ of the sample were between the ages of 20 and $34 ; 25.3 \%$ were 35 to 49 ; and $15.9 \%$ were aged 50 to 65. No respondents were more than 65-years-old, and only one respondent was less than 20years-old.

\section{The stimuli selection}

Instagram, a popular form of social media where users generate different types of content, was chosen for this study. Instagram was chosen because, despite its growing popularity, it hasn't drawn much scholarly attention, especially when it comes to examining its role in place branding and city image. Given the faster growth in the number of users than in other social networks such as Snapchat or Twitter (in April 2017, the number of users reached 700 million, up from 600 million in December 2016), Instagram represents one of the most popular social 
networks worldwide (Statista, 2017). Instagram has over 700 million registered active monthly users (Statista, 2017) and ranks among the most popular and engaging social media applications (Sheldon et al., 2017). According to Brandwatch (2016), a leading social intelligence company, 40 billion images have been posted on Instagram, and 3.5 billion daily "likes" and 80 million photo updates are posted daily. According to Zhu and Chen (2015), who created a social media classification typology that considers the nature of connection (profile-based versus contentbased) and the customization levels of messages (broadcast versus customized), Instagram should be regarded as a creative outlet. This is because it includes services that facilitate shared interests, creativity, and hobbies; users can follow whoever has the most interesting content and exchange advice and thoughts with each other. Instagram differentiates itself from other social media sites by emphasizing images above all else (Marwick, 2015). This characteristic enhances the relevance of Instagram because visual impressions can influence mid- and longterm human behaviour (Bergkvist, Eiderbäck, \& Palombo, 2012). For these reasons, this study decided to adopt Instagram stimuli and explain its relationship to the city branding process. Authors pre-tested manipulations of the stimuli related to the two independent variables (city image and social distance among users) through a questionnaire sent to a sample of 44 respondents. We retrieved data reaching members of the same social media groups addressed in the final study. The 44 respondents were not included in the final sample.

City image was treated as the independent variable. Authors manipulated the greenness of a city's image in order to create two different types of Instagram posts. Images from two lesser known cities were chosen because this allowed to control for other factors that might influence the responses to the questionnaire. In order to assess the reliability of the manipulation, authors tested the sample of respondents exposing them to images from both cities. A t-test confirmed the reliability of the manipulation. The respondents did not recognize the two cities and they indicated significantly different levels of greenness $(p=0.003)$. 
The second independent variable (social distance among users) was manipulated indicating to respondents that the images were posted by either visitors or the municipality itself. Social distance between these groups was assessed alongside the other dependent variable. Respondents were asked to report the extent to which they perceived the reviewer as socially close (similar to self, typical in-group member, and psychologically close). The results of this pre-test show that respondents perceive the municipality as more socially distant than other visitors $(p=0.042)$. All questions were on a 7-point scale, in accordance with guidelines set out by Kim, Zhang, and Li (2008).

\section{Procedure}

Data collection was carried out using an online survey. This approach results in a better response rate, while also allowing to randomize survey items and protect the confidentiality of the respondents (Machado et al., 2015). The survey was written in Italian and then sent to subjects in May and June of 2017. The respondents were located on social media and were randomly assigned - through the function of Qualtrics software - to four treatment conditions so that each cell contained approximately 45 subjects. Subjects were exposed to the same cover story explaining the nature of their tasks. Subjects were told that they have to imagine that they were scrolling through Instagram photos and compare images from each city. The cover story also revealed the author of the post (municipality or visitor). Respondents were then asked to indicate their attitude toward the city represented in the images. Attitude toward the city was measured by 3 items - very bad/very good; very worthless/very valuable; very unpleasant/very pleasant (Zarrad \& Debabi, 2015).

\section{Analysis and results}


A two-way ANOVA was performed on the responses of the various participants. Table 1 summarizes the result of the ANOVA.

Table 1. ANOVA Summary Table

\begin{tabular}{lllll}
\hline Source & $\mathrm{df}$ & MS & F & Sign \\
\hline Greeness & 1 & 22.29 & 12.49 & 0.01 \\
Social distance & 1 & 10.91 & 6.11 & 0.01 \\
Greeness * Social distance & 1 & 6.11 & 3.42 & 0.06 \\
Total & 182 & 1.78 & & \\
\hline
\end{tabular}

Note. - MS $=$ Mean squares

Subjects who were associated with the less green city image condition seem to have a less positive attitude toward the city (Mlow=4.42) than subjects in the greener city image condition (Mhigh=5.13). Indeed, the main effect of city image greenness on city attitude is significant $(p=0.00)$, which means that the first hypothesis $(\mathrm{H} 1)$ has been proven.

Subjects who were exposed to posts by municipalities have a less positive attitude towards the city (Mhigh=4.50) than subjects who were exposed to posts by visitors (Mlow=4.92). It would appear that distance among users of social media has a significant effect $(p=0.01)$ on city attitude. The second hypothesis (H2) was also supported. Authors also measured the interaction effect of the two variables. Data suggest that when the distance among users of social media is low, the attitude toward the city is more positive if the image of the city is green $(M=5.55)$ compared to when the distance among users is high $(\mathrm{M}=4.69)$. A significance of $p=0.06$ was ascertained, which means that the third hypothesis (H3) is partially supported. A plot of the interaction is reported in Figure 2 endorsing the directionality of our hypothesis. 
Figure 2. Plot of the interplay between green city image (high vs. low) and social distance (high vs. low) on attitude toward the city

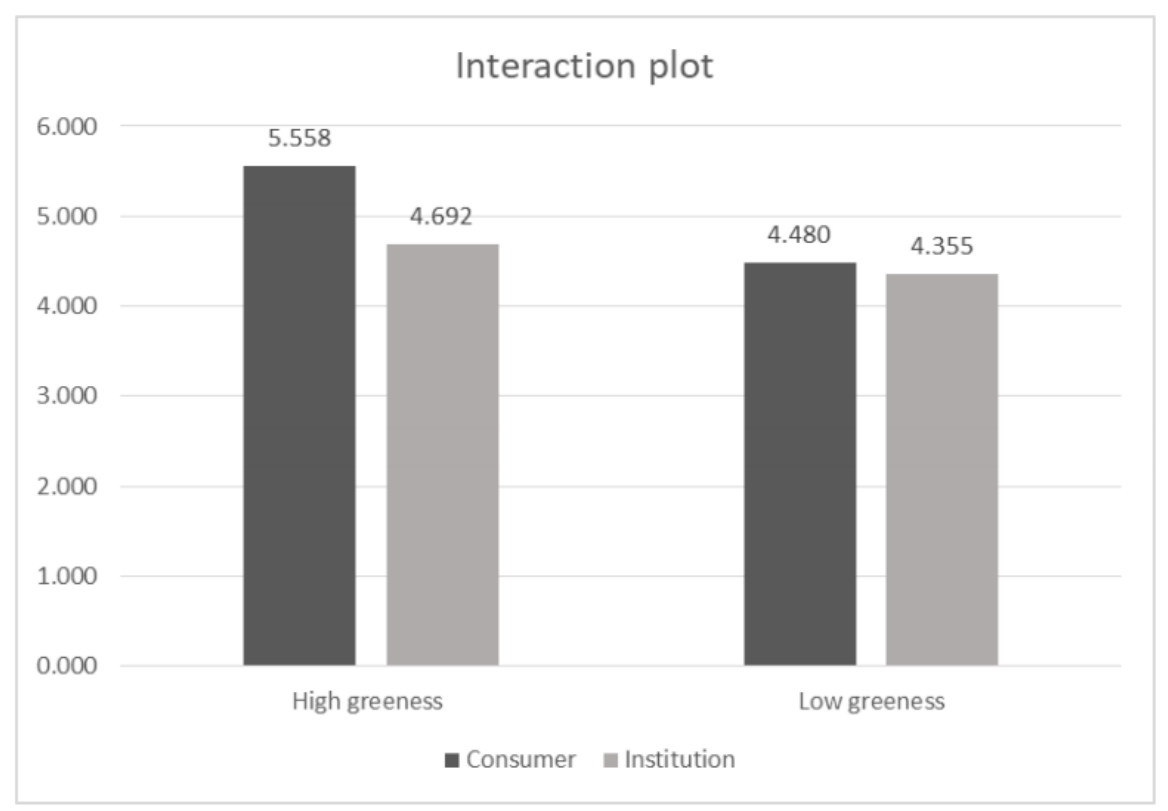

\section{Conclusions}

This study attempts to clarify the contribution of UGC in creating a place image and shaping the attitudes of potential visitors. The results provide support for the three hypotheses, suggesting that the image of a city and the author of social media content - the people who help create this image — affect users' attitudes toward the city. Indeed, the findings show that the attitude of potential visitors towards a city is more positive when the city image includes references to green living, including parks, green spaces, trees, and pastoral landscapes. In fact, growing awareness of the environmental impact of human activity over the past four decades has led to the creation of a more environmentally-minded society — one that appreciates sustainable products and services (Jones and Comfort, 2018). In particular, if on the one hand green characteristics of a city represent the respect of the environment also in the urban context, on the other hand attractive urban settlements embody human well-being. Organizations and institutions include this type of information in their place branding strategies in order to attract and positively influence the attitudes of different stakeholders. The results also show that the 
social distance between a potential visitor who sees a picture of a city and the user that posted it plays a role in determining how much influence UGC has on city attitude. Research findings do not exclude the usefulness of contents created by institutions in the creation of an appealing city image, but they suggest them to reduce the social distance perceived by users - for example using a particular way to write a post or selecting some style of picture taking. Moreover, the findings suggest that organizations and institutions encourage users to create and share content on social media related to the places they visit.

This study contributes to the literature on construal level theory assuming that perceived social distance is a very important issue within the research on social media content and the effect of UGC on the attitude and behaviour of other users. Accordingly, this study provides empirical evidence that organizations and institutions should encourage activities for the participation of people surrounding the cities (i.e. tourists, residents) to generate valuable content on social media to promote the green aspects of the city in an integrated marketing communication strategy perspective.

\section{Limitations and further research}

Although this study adds to our understanding of place branding, it has limitations that should be addressed by other researchers. For starters, the sample was made up solely of subjects who live in Italy. Of course, culture often plays an important role in influencing values and behaviours. Sustainable behaviour, in particular, cannot be reduced to individual behaviour alone, which means that a cross-national approach might help explain differences and similarities between countries and cultures (Ceglia et al., 2015). Future studies should focus on other countries in order to determine whether or not cultural factors affect attitudes toward certain cities. Moreover, this study focuses on green lifestyle because of its recent growth in popularity around the world (Unilever, 2017). Indeed, sustainability issues are a worldwide 
concern that continues to gain momentum, particularly in countries where growing populations are putting additional pressure on the environment. Nevertheless, it might be interesting to investigate also the influence of green city image on potential visitors who do not consider themselves supporters of the sustainability concept. Indeed, green cities are supposed to be more appealing to green lifestyle individuals than to others. However, some aspects linked to green cities can be suitable also for groups that are non-related to a sustainable lifestyle, such as the quality of life or the well-being. Future studies could extend the experiment to generic groups, allowing further comparison on the effect of the green image on attitude and behavior of stakeholders.

Furthermore, because of the growing interest among millennials in sustainable products and sustainable tourism, future studies should focus on this specific demographic. As many studies have reported, the new generation of sustainable tourists is being led by millennials who have a strong sense of civic and environmental responsibility and the desire to help people live better lives (Schoolman et al., 2016).

Authors interpreted green city image to mean the use of green resources — such as parks, green spaces, trees, and pastoral landscapes — to improve and revitalize a city's image. However, green city image can also refer to sustainable cities, eco-cities, transition towns, energy cities, or carbon-control regimes (Caprotti, 2014). As a result, defining the term green city image is a somewhat complicated task. Further research should consider other definitions of green city image, placing special emphasis on factors that specifically affect place branding activity. Finally, this paper shed light on the extent to which UGC shapes the attitudes of users, an area of interest that has thus far attracted little attention from academics. Authors hope that their study pushes other scholars to create similar studies that move beyond the mere intentions of users. Further research should examine how users actually behave once they encounter content that has been shared by other users. 


\section{References}

Acuti, D., Mazzoli, V., Donvito, R., \& Chan, P. 2018. An instagram content analysis for city branding in London and Florence. Journal of Global Fashion Marketing 9(3): 185-204. DOI: 10.1080/20932685.2018.1463859.

Adams, P. 2012. Grouped: How small groups of friends are the key to influence on the social web. California: New Riders.

Ahern, J. 2013. Urban landscape sustainability and resilience: the promise and challenges of integrating ecology with urban planning and design. Landscape Ecology 28(6): 1203-1212.

Alcázar, M.D.C.H., Piñero, M.S. and Maya, S.R.D., 2014. The effect of user-generated content on tourist behavior: the mediating role of destination image. Tourism \& Management Studies, 10 (ESPECIAL): 158-164.

Algesheimer, R., Dholakia, U. M., \& Herrmann, A. (2005). The social influence of brand community: Evidence from European car clubs. Journal of Marketing, 69(3): 19-34. DOI: https://doi.org/10.1509/jmkg.69.3.19.66363.

Andéhn. M., Kazeminia. A., Lucarelli. A. and Sevin. E. 2014. User-generated place brand equity on Twitter: The dynamics of brand associations in social media. Place Branding and Public Diplomacy 10(2): 132-144.

Anderberg, S. and Clark, E. 2013. Green sustainable Öresund region - or eco-branding Copenhagen and Malmö? In I. Vojnovic (Ed.), Sustainability: A global urban context (pp. 591610). Michigan State University Press. E-book. Retrieved from http://www.jstor.org/stable/10.14321/j.ctt130hjhm.

Andersen, S. M., Glassman, N. S. and Gold, D. A. 1998. Mental representations of the self, significant others, and nonsignificant others: Structure and processing of private and public 
aspects. Journal of personality and social psychology 75(4): 845. DOI: doi:10.1037/00223514.75.4.845.

Andersson, I. 2016. Green cities' going greener? Local environmental policy-making and place branding in the 'Greenest City in Europe. European Planning Studies 24(6): 1197-1215. DOI: 10.1080/09654313.2016.1152233.

Ayuso, S. 2006. Adoption of voluntary environmental tools for sustainable tourism: analysing the experience of Spanish hotels. Corporate Social Responsibility and Environmental Management, 13(4): 207-220. DOI: 10.1002/csr.103.

Bagozzi, R. P., \& Dholakia, U. M. (2002). Intentional social action in virtual communities. Journal of Interactive Marketing, 16(2): 2-21. DOI: 10.1002/dir.10006.

Bakhshi, S., Shamma, D. A., \& Gilbert, E. 2014. Faces engage us: Photos with faces attract more likes and comments on instagram. In Proceedings of the SIGCHI Conference on Human Factors in Computing Systems: 965-974. ACM.

Baloglu, S. and McCleary, K. W. 1999. A model of destination image formation. Annals of tourism research 26(4): 868-897. DOI: https://doi.org/10.1016/S0160-7383(99)00030-4.

Barger, V., Peltier, J.W., and Schultz, D.E. 2016. Social media and consumer engagement: a review and research agenda. Journal of Research in Interactive Marketing 10(4): 268-287.

Bedard, S. A. N., \& Tolmie, C. R. 2018. Millennials' green consumption behaviour: Exploring the role of social media. Corporate Social Responsibility and Environmental Management. DOI: $10.1002 /$ csr. 1654 .

Bell, F. 2016. Looking beyond place branding: the emergence of place reputation. Journal of Place Management and Development, 9(3): 247-254. DOI: 10.1108/JPMD-08-2016-0055. 
Bergkvist, L. Eiderbäck, D. and Palombo, M. 2012. The brand communication effects of using a headline to prompt the key benefit in ads with pictorial metaphors. Journal of Advertising 41( 2): 67-76. DOI: 10.2753/JOA0091-3367410205.

Berscheid, E. 1985. Interpersonal attraction",in Lindzey, G.; Aronson, E., (Ed.), Handbook of social psychology, Random House, New York: 413-484. DOI: 10.1002/9780470561119.

Bertino, M. 2014. "New research: Topics that get a reaction". Retrieved October 19, 2017, from http://kloutblog.lithium.com/t5/Klout-Blog/New-Research-Topics-That-Get-A-Reaction/ba$\mathrm{p} / 578$.

Brandwatch. 2016. Retrieved at https://www.brandwatch.com/blog/37-instagram-stats-2016/.

Braun, E., Kavaratzis, M. and Zenker, S. 2013. My city-my brand: the different roles of residents in place branding. Journal of Place Management and Development 6(1): 18-28. DOI: https://doi.org/10.1108/17538331311306087.

Bronner, F. and De Hoog, R. 2011. Vacationers and eWOM: Who posts, and why, where, and what?. Journal of Travel Research 50(1): 15-26. DOI: $10.1177 / 0047287509355324$.

Buhalis, D. and Foerste, M., 2015. SoCoMo marketing for travel and tourism: Empowering cocreation of value. Journal of destination marketing \& management, 4(3): 51-161. DOI: https://doi.org/10.1016/j.jdmm.2015.04.001

Bulkeley, H., \& Betsill, M. 2005. Rethinking sustainable cities: Multilevel governance and the'urban'politics of climate change. Environmental politics, 14(1): 42-63. DOI: 10.1080/0964401042000310178.

Byrne, D., Clore Jr, G. L. and Worchel, P. 1966. Effect of economic similarity-dissimilarity on interpersonal attraction. Journal of Personality and Social Psychology 4(2): 220. 
Cai, L. A. 2002. Cooperative branding for rural destinations. Annals of tourism research 29(3): 720-742. DOI: https://doi.org/10.1016/S0160-7383(01)00080-9..

Caprotti, F. 2014. Critical research on eco-cities? A walk through the Sino-Singapore Tianjin ecocity, China. Cities 36: 10-17. DOI: https://doi.org/10.1016/j.cities.2013.08.005.

Ceglia, D., Lima, O., Henrique, S. and Leocádio, Á. L. 2015. An Alternative Theoretical Discussion on Cross-Cultural Sustainable Consumption. Sustainable Development 23(6): 414424. DOI: https://doi.org/10.1002/sd.1600.

Chan, C. S., Chan, C. S., Marafa, L. M. and Marafa, L. M. 2016. The green branding of Hong Kong: visitors' and residents' perceptions. Journal of Place Management and Development 9(3): 289-312. DOI: https://doi.org/10.1108/JPMD-02-2016-0008.

Cheng, M., Wong, I. A., Wearing, S. and McDonald, M. 2017. Ecotourism social media initiatives in China. Journal of Sustainable Tourism,25(3): 416-432. DOI: https://doi.org/10.1080/09669582.2016.1214141.

Choi. S. Lehto. X. Y. \& Morrison. A. M. 2007. Destination image representation on the web: Content analysis of Macau travel related websites. Tourism Management. 28(1): 118-129. Doi: 10.1016/j.tourman.2006.03.002.

Cialdini, R. B., \& Goldstein, N. J. 2004. Social influence: Compliance and conformity. Annual Review of Psychology, 55: 591-621. DOI: https://doi.org/10.1146/annurev.psych.55.090902.142015.

Daugherty, T., Eastin, M.S. and Bright, L. 2008. Exploring consumer motivations for creating user-generated content. Journal of Interactive Advertising, 8(2): 16-25. DOI: https://doi.org/10.1080/15252019.2008.10722139. 
Dessart, L., Veloutsou, C. and Morgan-Thomas, A. 2015. Consumer engagement in online brand communities: a social media perspective. Journal of Product \& Brand Management 24(1): 28-42. DOI: https://doi.org/10.1108/JPBM-06-2014-0635.

de Rosa, A.S., Bocci, E. and Dryjanska, L., 2017. Social representations of the European capitals and destination e-branding via multi-channel web communication. Journal of Destination Marketing \& Management. DOI: https://doi.org/10.1016/j.jdmm.2017.05.004

Dinnie, K. 2015. Nation branding: Concepts, issues, practice. Routledge.

Divine, R. L. and Lepisto, L. 2005. Analysis of the healthy lifestyle consumer. Journal of Consumer Marketing, 22(5): 275-283. DOI: https://doi.org/10.1108/0736376051.

Dholakia, U. M., Bagozzi, R. P., \& Pearo, L. K. 2004. A social influence model of consumer participation in network-and small-group-based virtual communities. International Journal of Research in Marketing, 21(3): 241-263. DOI: https://doi.org/10.1016/j.ijresmar.2003.12.004.

Do Paço, Arminda M. Finisterra and Mário Lino Barata Raposo. 2010. Green Consumer Market Segmentation: Empirical Findings from Portugal. International Journal of Consumer Studies 34(4): 429-436. DOI: https://doi.org/10.1111/j.1470-6431.2010.00869.x.

Duhachek, A., Zhang, S. and Krishnan, S. 2007. Anticipated group interaction: coping with valence asymmetries in attitude shift. Journal of Consumer Research 34(3): 395-405. DOI: https://doi.org/10.1086/518543.

Fiedler, K., Semin, G. R., Finkenauer, C. and Berkel, I. 1995. Actor-observer bias in close relationships: The role of self-knowledge and self-related language. Personality and Social Psychology Bulletin 21(5): 525-538. DOI: https://doi.org/10.1177/0146167295215010.

Florenthal, B., \& Arling, P. 2011. Do green lifestyle consumers appreciate low involvement green products?. Marketing Management Journal 21(2): 35. 
Foroudi, P., Gupta, S., Kitchen, P., Foroudi, M.M. and Nguyen, B. 2016. A framework of place branding, place image, and place reputation: Antecedents and moderators. Qualitative Market Research: An International Journal 19(2): 241-264. DOI: https://doi.org/10.1108/QMR-022016-0020.

Fotis, J. Buhalis, D. and Rossides, N. 2012. Social media use and impact during the holiday travel planning process, Springer-Verlag, pp. 13-24. Retreived at: http://www.springerlink.com.

Friedman, A. and Miles, S. 2002. Developing stakeholder theory. Journal of Management Studies 39(1): 1-21. DOI: https://doi.org/10.1111/1467-6486.00280.

Freire, J. R. 2005. Geo-branding, are we talking nonsense? A theoretical reflection on brands applied to places. Place Branding 1(4): 347-362. DOI: https://doi.org/10.1057/palgrave.pb.5990033.

Gallarza, M. G., Saura, I. G. and García, H. C. 2002. Destination image: Towards a conceptual framework. Annals of tourism research 29(1): 56-78. DOI: https://doi.org/10.1016/S01607383(01)00031-7.

Gershoff, A. D. and Frels, J. K. 2014. What makes it green? The role of centrality of green attributes in evaluations of the greenness of products. American Marketing Association 79(1). DOI: $\underline{\text { https://doi.org/10.1509/jm.13.0303. }}$

Geuens, M., \& De Pelsmacker, P. (2017). Planning and conducting experimental advertising research and questionnaire design. Journal of Advertising,46(1): 83-100. DOI: https://doi.org/10.1080/00913367.2016.1225233. 
Gilboa, E. 2008. Searching for a theory of public diplomacy. The ANNALS of the American Academy of Political and Social Science 616(1): 55-77. DOI: https://doi.org/10.1177/0002716207312142.

Gulsrud, N. M., Gooding, S. and Konijnendijk Van Den Bosch, C. C. 2013. Green space branding in Denmark in an era of neoliberal governance. Urban Forestry \& Urban Greening 12(3): 330-337. DOI: https://doi.org/10.1016/j.ufug.2013.03.001.

Hankinson.G. 2006. The management of destination brands: Five guiding principles based on recent developments in corporate branding theory. Brand Mangagement 14(3): 240-254. DOI https://doi.org/10.1057/palgrave.bm.2550065.

Hao, Y., Farooq, Q., \& Sun, Y. 2018. Development of theoretical framework and measures for the role of social media in realizing corporate social responsibility through native and nonnative communication modes: Moderating effects of cross-cultural management. Corporate Social Responsibility and Environmental Management, 25(4): 704-711. DOI: 10.1002/csr1523.

Harjoto, M. A. and Salas, J. 2017. Strategic and institutional sustainability: corporate social responsibility, brand value, and interbrand listing. Journal of Product \& Brand Management,26 (6): 545-558. DOI: https://doi.org/10.1108/JPBM-07-2016-1277.

Hennig-Thurau, T., Gwinner, K.P., Walsh, G. and Gremler, D.D. 2004. Electronic word-ofmouth via consumer-opinion platforms: what motivates consumers to articulate themselves on the internet?.Journal of interactive marketing 18(1): 38-52. DOI: https://doi.org/10.1002/dir.10073.

Heyes, A. (2017). Introduction to Mediation, Moderation, and Conditional Process Analysis, Second Edition: A Regression-Based Approach. UK: Guilford Publications. 
Insch, A. 2011. Branding the City as an Attractive Place to Live. in K. Dinnie (Ed.), City Branding_Theory and Cases, Basingstoke: Palgrave Macmillan: 8-14.

Jalilvand, M. and Samiei, N. 2012. The effect of electronic word of mouth on brand image and purchase intention: An empirical study in the automobile industry in Iran. Marketing Intelligence \& Planning 30(4): 460-476. DOI: https://doi.org/10.1108/02634501211.

Jenkins, O. H. 1999. Understanding and measuring tourist destination images. International journal of tourism research, 1(1): 1-15.

Jim, C. Y. and Chen, W. Y. 2006. Perception and attitude of residents toward urban green spaces in Guangzhou (China). Environmental management 38(3): 338-349. DOI: https://doi.org/10.1007/s00267-005-0166-6.

Jim, C.Y. 2002. Planning strategies to overcome constraints on greenspace provision in urban Hong Kong. Town Planning Review 73(2): 127-152. DOI: https://doi.org/10.3828/tpr.73.2.1.

Jones, P., and Comfort, D. 2018. Sustainable Consumption and the Leading US Retailers. Indonesian Journal of Corporate Social Responsibility and Environmental Management, 1(1). DOI: https://doi.org/10.28992/ijcsrem.v1i1.17.

Kang, S., \& Hur, W. M. 2012. Investigating the antecedents of green brand equity: a sustainable development perspective. Corporate Social Responsibility and Environmental Management, 19(5): 306-316. DOI: 10.1002/csr.281.

Kaplan, A.M. and Haenlein, M. 2010. Users of the world, unite! The challenges and opportunities of Social Media. Business horizons 53(1): 59-68.

Kavaratzis, M. 2005. Place branding: A review of trends and conceptual models. The Marketing Review 5(4): 329-342. DOI: https://doi.org/10.1362/146934705775186854. 
Kavaratzis, M., \& Ashworth, G. J. (2005). City branding: an effective assertion of identity or a transitory marketing trick?. Tijdschrift voor economische en sociale geografie, 96(5): 506-514. DOI: https://doi.org/10.1111/j.1467-9663.2005.00482.x

Kim, A. J., and Ko, E. 2012. Do social media marketing activities enhance customer equity? An empirical study of luxury fashion brand. Journal of Business Research, 65(10): 1480-1486. DOI: 10.1016/j.jbusres.2011.10.014.

Kim, A. J., \& Johnson, K. K. 2016. Power of consumers using social media: Examining the influences of brand-related user-generated content on Facebook. Computers in Human Behavior, 58: 98-108.

Kim, K., Zhang, M. and Li, X. 2008. Effects of temporal and social distance on consumer evaluations. Journal of Consumer Research 35(4): 706-713. DOI: https://doi.org/10.1086/592131.

Kladou, S., Kavaratzis, M., Rigopoulou, E. and Salonika, E. 2016. The role of brand elements in destination branding. Journal of Destination Marketing \& Management. 6 (4): 426-435. DOI: https://doi.org/10.1016/j.jdmm.2016.06.011.

Klage, J. P. 1991. Corporate identity im Kreditwesen, Deutscher Universität Verlag, Wiesbaden.

Köhler, C. F., Rohm, A. J., de Ruyter, K., \& Wetzels, M. 2011. Return on interactivity: The impact of online agents on newcomer adjustment. Journal of Marketing, 75(2): 93-108.

Korhonen, J., Niemeläinen, H., \& Pulliainen, K. 2002. Regional industrial recycling network in energy supply - the case of Joensuu city, Finland. Corporate Social Responsibility and Environmental Management, 9(3): 170-185. DOI: https://doi.org/10.1002/csr.20. 
Kotler, P., \& Gertner, D. 2002. Country as brand, product, and beyond: A place marketing and brand management perspective. Journal of brand management,9(4): 249-261. DOI: https://doi.org/10.1057/palgrave.bm.2540076

Labrecque, L. I., Esche, J. V. D., Mathwick, C., Novak, T. P. and Hofacker, C. F. 2013. Consumer power: Evolution in the digital age. Journal of Interactive Marketing 27: 257-269. DOI: https://doi.org/10.1016/j.intmar.2013.09.002.

Laroche, M., Bergeron, J. and Barbaro-Forleo, G. 2001. Targeting consumers who are willing to pay more for environmentally friendly products. Journal of consumer marketing 18 (6): 503520. DOI: https://doi.org/10.1108/EUM000000.

Liberman, N. and Trope, Y. 1998. The role of feasibility and desirability considerations in near and distant future decisions: A test of temporal construal theory. Journal of Personality and Social Psychology 75(1): 5-18.

Line, N. D., Hanks, L. and Zhang, L. 2016. Sustainability communication: The effect of message construals on consumers' attitudes towards green restaurants. International Journal of Hospitality Management 57: 143-151. DOI: https://doi.org/10.1016/j.ijhm.2016.07.001.

Liu, X., Burns, A. C., \& Hou, Y. 2017. An investigation of brand-related user-generated content on Twitter. Journal of Advertising, 46(2): 236-247. DOI: https://doi.org/10.1080/00913367.2017.1297273

Liviatan, I., Trope, Y. and Liberman, N. 2008. Interpersonal similarity as a social distance dimension: Implications for perception of others' actions. Journal of experimental social psychology 44(5): 1256-1269. DOI: https://doi.org/10.1016/j.jesp.2008.04.007. 
Lund, N.F., Cohen, S.A. and Scarles, C. 2017. The power of social media storytelling in destination branding. Journal of Destination Marketing \& Management. (In press). DOI: https://doi.org/10.1016/j.jdmm.2017.05.003.

Machado, J. C., de Carvalho, L. V., Torres, A. and Costa, P. 2015. Brand logo design: examining consumer response to naturalness. Journal of Product \& Brand Management 24(1): 78-87. DOI: https://doi.org/10.1108/JPBM-05-2014-0609.

Martin, D., Woodside, A. G. and Dehuang, N. 2007. Etic interpreting of naïve subjective personal introspections of tourism behavior: Analyzing Visitors' stories about experiencing Mumbai, Seoul, Singapore, and Tokyo. International Journal of Culture, Tourism, \& Hospitality Research 1(1): 14-44. DOI: https://doi.org/10.1108/17506180710.

Nambisan, S., \& Baron, R. A. 2007. Interactions in virtual customer environments: Implications for product support and customer relationship management. Journal of Interactive Marketing, 21(2): 42-62. DOI: https://doi.org/10.1002/dir.20077.

Oliveira, E., \& Panyik, E. 2015. Content, context and co-creation: Digital challenges in destination branding with references to Portugal as a tourist destination. Journal of Vacation Marketing, 21(1): 53-74. DOI: 10.1177/1356766714544235.

Pike, S. 2009. Destination brand positions of a competitive set of near-home destinations. Tourism Management 30(6): 857-866. DOI: https://doi.org/10.1016/j.tourman.2008.12.007.

Rahmawati, R., Gantyowati, E., Agustiningsih, S. W., \& Soenarto, S. 2018. Solo Creative City Network: Development of Household Waste Creative Industry as Market Engine of Tourism Industry. Indonesian Journal of Corporate Social Responsibility and Environmental Management, 1(1). DOI: https://doi.org/10.28992/ijcsrem.v1i1.15. 
Schivinski, B., \& Dabrowski, D. 2016. The effect of social media communication on consumer perceptions of brands. Journal of Marketing Communications, 22(2): 189-214. DOI: $10.1080 / 13527266.2013 .871323$.

Schoolman, E. D., Shriberg, M., Schwimmer, S. and Tysman, M. 2016. Green cities and ivory towers: how do higher education sustainability initiatives shape millennials' consumption practices?. Journal of Environmental Studies and Sciences, 6(3): 490-502. DOI: https://doi.org/10.1007/s13412-014-0190-z.

Sevin, H. E. 2014. Understanding cities through city brands: City branding as a social and semantic network. Cities 38: 47-56. DOI: https://doi.org/10.1016/j.cities.2014.01.003.

Sheldon, P., Rauschnabel, P. A., Antony, M. G. and Car, S. 2017. A cross-cultural comparison of Croatian and American social network sites: Exploring cultural differences in motives for Instagram use. Computers in Human Behavior 75: 643-651. DOI: https://doi.org/10.1016/j.chb.2017.06.009.

Statista. 2017. Retrieved at https://www.statista.com/statistics/253577/number-of-monthlyactive-instagram-users/.

Stewart, D.W., Pavlou, P.A. 2002. From consumer response to active consumer: measuring the effectiveness of interactive media. Journal of the Academy of Marketing Science 30(4): 376396. DOI: $10.1177 \mathrm{t} 009207002236912$.

Szondi, G. 2010. From image management to relationship building: A public relations approach to nation branding. Place Branding and Public Diplomacy 6(4): 333-343. DOI: https://doi.org/10.1057/pb.2010.32. 
Thornton, L. J. 2014. The Photo Is Live at Applifam: An Instagram Community Grapples With How Images Should Be Used. Visual Communication Quarterly 21(2): 72-82. DOI: https://doi.org/10.1080/15551393.2014.928147.

Trope, Y., and Liberman, N. 2003. Temporal construal. Psychological Review 110(3): 403.

Trope, Y. and Liberman, N. 2010. Construal-level theory of psychological distance. Psychological Review 117(2): 440.

Tzoulas, K., Korpela, K., Venn, S., Yli-Pelkonen, V., Kaźmierczak, A., Niemela, J. and James, P. 2007. Promoting ecosystem and human health in urban areas using Green infrastuctures: A literature review. Landscape and Urban Planning 81: 167-178. DOI: https://doi.org/10.1016/j.landurbplan.2007.02.001.

Unilever, 2017. Retrieved at https://www.unilever.com/news/Press-releases/2017/reportshows-a-third-of-consumers-prefer-sustainable-brands.html.

Van Kamp, I., Leidelmeijer, K., Marsman, G., \& De Hollander, A. 2003. Urban environmental quality and human well-being: Towards a conceptual framework and demarcation of concepts; a literature study. Landscape and urban planning 65(1-2): 5-18.

Wang, X., Yu, C., \& Wei, Y. 2012. Social media peer communication and impacts on purchase intentions: A consumer socialization framework. Journal of interactive marketing, 26(4): 198208.

Yan, Y., Wang, C., Quan, Y., Wu, G., \& Zhao, J. 2018. Urban sustainable development efficiency towards the balance between nature and human well-being: Connotation, measurement, and assessment. Journal of Cleaner Production 178: 67-75. 
Yoo, K. -H., Lee, Y. -J., Gretzel, U., \& Fesenmaier, D. R. (2009). Trust in travel-related consumer generated media. In W. Höpken, U. Gretzel, \& R. Law (Eds.), Information and communication technologies in tourism, 2009 (pp. 49-60). Vienna, Austria: Springer Verlag.

Zarrad, H. and Debabi, M. 2015. Analyzing the effect of electronic word of mouth on tourists' attitude toward destination and travel intention. International research journal of social $\begin{array}{llll}\text { sciences } & 4(4): & \text { Retrieved } & \text { at }\end{array}$ https://pdfs.semanticscholar.org/351a/1560556ca00e6a11e5e2e895e23e95473063.pdf.

Zeng, B., \& Gerritsen, R. (2014). What do we know about social media in tourism? A review. $\begin{array}{llll}\text { Tourism } \quad \text { Management } & \text { Perspectives, } & \text { 10: } & \text { DOI: }\end{array}$ https://doi.org/10.1016/j.tmp.2014.01.001.

Zhang, K. and Sarvary, M. 2014. Differentiation with user-generated content. Management Science 61(4): 898-914. DOI: https://doi.org/10.1287/mnsc.2014.1907.

Zhu, Y. Q. and Chen, H. G. 2015. Social media and human need satisfaction: Implications for social media marketing. Business horizons 58(3): 335-345. DOI: https://doi.org/10.1016/j.bushor.2015.01.006. 